\title{
ZNF281 wt Allele
}

National Cancer Institute

\section{Source}

National Cancer Institute. ZNF281 wt Allele. NCI Thesaurus. Code C114741.

Human ZNF281 wild-type allele is located in the vicinity of $1 \mathrm{q} 32.1$ and is approximately 4 $\mathrm{kb}$ in length. This allele, which encodes zinc finger protein 281 , plays a role in the regulation of cell differentiation and the modulation of gene transcription. 